\title{
Hydrogen production from decalin dehydrogenation over Pt-Ni/C bimetallic catalysts
}

\author{
Suitao Qi*, Yingying Li, Jiaqi Yue, Hao Chen, Chunhai Yi, Bolun Yang \\ School of Chemical Engineering and Technology, Xi'an Jiaotong University, Xi'an 710049, Shaanxi, China
}

\section{A R T I C L E I N F O}

Article history:

Received 6 April 2014

Accepted 23 May 2014

Published 20 November 2014

\section{Keywords:}

Platinum

Nickel

Bimetallic

Decalin

Dehydrogenation

Density functional theory

\begin{abstract}
A B S T R A C T
Pt-Ni bimetallic catalysts and the corresponding monometallic Pt catalysts supported on active carbon were prepared by incipient wetness impregnation and characterized by X-ray diffraction, $\mathrm{N}_{2}$ adsorption, and $\mathrm{NH}_{3}$-temperature programmed desorption. Their activities for decalin dehydrogenation were investigated at a superheated liquid film state in a batch reactor. The effects of temperature, impregnation sequence, and $\mathrm{Pt} / \mathrm{Ni}$ molar ratio on the dehydrogenation activity and the naphthalene yield were investigated. The results show that the Pt-Ni bimetallic catalyst significantly enhanced hydrogen evolution compared with either Ni or Pt monometallic catalyst. The highest dehydrogenation conversion and naphthalene yield were obtained when the Pt/Ni molar ratio was 1:1 and Pt was impregnated first. The experimental results were correlated with density functional theory calculations of hydrogen binding energy (HBE) on different catalytic surfaces. The correlation confirmed that bimetallic surfaces with stronger HBEs had higher dehydrogenation activities.
\end{abstract}

(C) 2014, Dalian Institute of Chemical Physics, Chinese Academy of Sciences. Published by Elsevier B.V. All rights reserved.

\section{Introduction}

Hydrogen as a clean energy carrier has good prospects in hydrogen fuel cells and alternative energy sources. However, the key to using hydrogen on a large scale lies in its storage, transportation, and distribution [1,2]. Some cyclic hydrocarbons such as decalin, tetralin, and cyclohexane are receiving an increasing amount of attention as organic liquid hydrogen storage materials [3-13]. Their hydrogenation and dehydrogenation cycles offer the possibility of using these molecules as hydrogen storage media because of their high hydrogen storage density and convenient transportation.

Among all the liquid organic hydrides, decalin is one of the best candidates because of its excellent hydrogen storage density of $7.2 \mathrm{wt} \%$. Moreover, decalin is an environmentally friendly hydrogen carrier with zero $\mathrm{CO}_{2}$ emission in the dehy- drogenation process [14-21]. It is well known that the decalin dehydrogenation reaction is an endothermic reaction. Higher temperatures would be favorable for dehydrogenation, but the selectivity toward naphthalene would decrease because of side effects such as hydrogenolysis or coking at high temperatures. These side reactions would hinder the reversible cycle of hydrogen storage and release.

Bimetallic catalysts [22-24], which often show distinctly different electronic and chemical properties from those of the parent metals, offer the opportunity to design new catalytic materials with enhanced activity, selectivity, and stability. Kariya et al. [7] reported that Pt-Re, Pt-Pd, and Pt-Rh catalyzed cycloalkane dehydrogenation better than Pt monometallic catalysts. However, high cost prohibits widespread use of noble metal catalysts, so some metal oxide catalysts have been investigated in the dehydrogenation reaction [25].

\footnotetext{
*Corresponding author. Tel: +86-29-82663189; E-mail: suitaoqi@mail.xjtu.edu.cn
}

This work was supported by the National Natural Science Foundation of China (21006076), the Specialized Research Fund for the Doctoral Program of Higher Education, China (20110201130002), and the Fundamental Research Funds for the Central Universities, China (xjj2011062).

DOI: 10.1016/S1872-2067(14)60178-9 | http://www.sciencedirect.com/science/journal/18722067 | Chin. J. Catal., Vol. 35, No. 11, November 2014 
In our previous work, the Pt-Ni bimetallic catalyst was identified as an active catalyst toward low-temperature hydrogenation and dehydrogenation of cycloalkenes including cyclohexene, 1,3-cyclohexadiene, and 1,4-cyclohexadiene [26-28]. Both experimental and theoretical investigations have revealed that for the Pt-Ni bimetallic catalyst, the formation of a subsurface Pt-Ni-Pt structure with an atomic layer of Ni underneath the surface Pt atoms is responsible for the higher hydrogenation activity than the corresponding monometallic surfaces. In contrast, a surface bimetallic structure, Ni-Pt-Pt, with a layer of $\mathrm{Ni}$ residing on top of the Pt substrate, binds adsorbates more strongly than either the Pt or Ni surfaces alone [29,30]. The strong binding on the Ni-Pt-Pt surface structure leads to facile production of hydrogen from the dehydrogenation of cycloalkenes, oxygenates [31], and ammonia [32].

This work extends the previous surface science results to supported Pt-Ni bimetallic catalysts prepared by the incipient wetness impregnation method. Decalin dehydrogenation was selected as a probe reaction to demonstrate the enhanced dehydrogenation activity on the bimetallic catalysts. The dehydrogenation activity of the $\mathrm{Pt}-\mathrm{Ni} / \mathrm{C}$ bimetallic catalyst was compared with those of the corresponding monometallic $\mathrm{Pt}$ and Ni catalysts. It was found that supported Pt-Ni bimetallic catalysts exhibited much better performance than either of the monometallic catalysts. On the other hand, for the Pt-Ni bimetallic catalyst, an effect of the impregnation sequence was observed and discussed. In addition, the catalytic activity and hydrogen binding energy (HBE) on different Pt-Ni surfaces from density functional theory (DFT) calculations were shown to be correlated $[33,34]$.

\section{Experimental}

\subsection{Catalyst preparation}

A series of $\mathrm{Ni}$ or Pt catalysts were prepared by the incipient wetness impregnation method. $\mathrm{Ni}\left(\mathrm{NO}_{3}\right)_{2} \cdot 6 \mathrm{H}_{2} \mathrm{O}$ (AR, Tianjin Chemical Reagent Research Institute, China) or chloroplatinic acid (AR) was selected as the source of active metal and impregnated into active carbon (C). The Pt-Ni bimetallic catalysts were prepared by sequential impregnation and co-impregnation. After impregnation, the different precursors were dried at $110{ }^{\circ} \mathrm{C}$ for $2 \mathrm{~h}$ and then calcined in $\mathrm{N}_{2}$ atmosphere at $400{ }^{\circ} \mathrm{C}$ for $1 \mathrm{~h}$. The different bimetallic catalysts are denoted $1 \mathrm{Pt}-1 \mathrm{Ni} / \mathrm{C}(\mathrm{CI}), 1 \mathrm{Pt}-1 \mathrm{Ni} / \mathrm{C}$, and $1 \mathrm{Ni}-1 \mathrm{Pt} / \mathrm{C}$. Pt-Ni/C(CI) means that the catalyst was prepared by $\mathrm{Pt}$ and $\mathrm{Ni}$ co-impregnation. $\mathrm{Pt}-\mathrm{Ni} / \mathrm{C}$ means that $\mathrm{Ni}$ was impregnated first, while $\mathrm{Ni}-\mathrm{Pt} / \mathrm{C}$ means that Pt was impregnated first. $1 \mathrm{Pt}-1 \mathrm{Ni}$ indicates that the atomic ratio of Pt to $\mathrm{Ni}$ was 1:1. Other Pt-Ni bimetallic catalysts with different $\mathrm{Pt} / \mathrm{Ni}$ ratios were also prepared for comparisons to the $1 \mathrm{Pt}-1 \mathrm{Ni}$ catalysts. They are denoted $0.5 \mathrm{Ni}-1 \mathrm{Pt} / \mathrm{C}$, $2 \mathrm{Ni}-1 \mathrm{Pt} / \mathrm{C}, 4 \mathrm{Ni}-1 \mathrm{Pt} / \mathrm{C}$, and $8 \mathrm{Ni}-1 \mathrm{Pt} / \mathrm{C}$. Pt loadings of all catalysts were $3 \mathrm{wt} \%$.

\subsection{Catalyst characterization}

The specific surface area and pore volume measurements of the different catalysts were measured by $\mathrm{N}_{2}$ adsorption-desorption at liquid nitrogen temperature using a Beckman Coulter Sorption Analysis 3100 Plus instrument. Powder X-ray diffraction (XRD) patterns of various catalysts were recorded with a Rigaku D/Max-2400 X-ray diffractometer using $\mathrm{Cu} K_{\alpha}$ radiation with a scanning angle $(2 \theta)$ range of $5^{\circ}-80^{\circ}$, operated at 36 $\mathrm{kV}$ and $80 \mathrm{~mA}$. $\mathrm{NH}_{3}$-temperature programmed desorption ( $\mathrm{NH}_{3}$-TPD) tests were performed to determine the catalyst surface acidity. In a U-shaped tubular quartz reactor heated by an electric furnace, $0.1 \mathrm{~g}$ sample was pretreated in flowing $\mathrm{He}$ (99.99\%, $30 \mathrm{~mL} / \mathrm{min}$ ) at $400{ }^{\circ} \mathrm{C}$ for $0.5 \mathrm{~h}$, followed by $\mathrm{NH}_{3}$ saturated adsorption at $30^{\circ} \mathrm{C}$, and then flushed with flowing $\mathrm{He}$ at the same temperature for $1 \mathrm{~h}$. $\mathrm{NH}_{3}$-TPD experiments were performed using a temperature ramp from 30 to $600{ }^{\circ} \mathrm{C}$ at 10 ${ }^{\circ} \mathrm{C} / \mathrm{min}$ using a thermal conductivity detector.

\subsection{Catalyst evaluation}

The catalytic activities of different catalysts for decalin dehydrogenation were evaluated using a batch reactor. The batch reactor consisted of a three-necked flat-bottomed flask of 100 $\mathrm{mL}$ capacity, fitted with a condenser in the central opening. A sampling device and a thermocouple were fitted in the other two openings. The reaction temperature was maintained by an electric furnace equipped with a temperature controller.

In a typical run, $0.3 \mathrm{~g}$ catalyst was added into the bottom of the flask and reduced with $\mathrm{H}_{2}$ for $1 \mathrm{~h}$ at the reaction temperature, and then the reactor was flushed with flowing $\mathrm{N}_{2}$ for $0.5 \mathrm{~h}$ to remove residual $\mathrm{H}_{2}$. Thereafter, $1 \mathrm{~mL}$ decalin $(6.48 \mathrm{mmol}$ ) was added to the reactor, and the reaction started and was allowed to proceed for $0.5 \mathrm{~h}$. During the reaction, the continuous vaporization-condensation reflux of decalin ensured the formation of a decalin liquid film on the catalyst surface, which remained covered by the decalin liquid film. The temperature of the catalyst surface was higher than the boiling point of decalin, which was in an overheated state. The evolving $\mathrm{H}_{2}$ was collected and measured by the water drainage method. After the reaction, the contents remaining in the flask were dissolved with $n$-hexane. The dissolved mixture was collected and separated by centrifugation to remove the catalyst particles completely, and then analyzed by a HP-4890D gas chromatograph equipped with a flame ionization detector. The yield of naphthalene was calculated by dividing the moles of naphthalene actually obtained by the moles of naphthalene theoretically obtained.

\section{Results and discussion}

Table 1 lists the surface area and average pore diameter of the different catalysts. The addition of metal leads to a small decrease in the catalyst surface area, which indicates that metal species on the support might migrate into internal channels after calcination. The surface area of the Pt-Ni bimetallic catalysts decreases with increasing $\mathrm{Ni}$ content, following the order $1 \mathrm{Ni}-1 \mathrm{Pt} / \mathrm{C}>1 \mathrm{Pt}-1 \mathrm{Ni} / \mathrm{C}(\mathrm{CI})>1 \mathrm{Pt}-1 \mathrm{Ni} / \mathrm{C}$. For the decalin dehydrogenation reaction, smaller pore sizes can prevent diffusion of the intermediate product tetralin and help tetralin further 
Table 1

Surface area and average pore diameter of different catalyst samples.

\begin{tabular}{lcc}
\hline Catalyst & $\begin{array}{c}\text { Surface area } \\
\left(\mathrm{m}^{2} / \mathrm{g}\right)\end{array}$ & $\begin{array}{c}\text { Average pore diameter } \\
(\mathrm{nm})\end{array}$ \\
\hline $\mathrm{C}$ & 407 & 8.6 \\
$\mathrm{Pt} / \mathrm{C}$ & 360 & 9.7 \\
$1 \mathrm{Pt}-1 \mathrm{Ni} / \mathrm{C}(\mathrm{CI})$ & 340 & 10.3 \\
$1 \mathrm{Pt}-1 \mathrm{Ni} / \mathrm{C}$ & 318 & 11.0 \\
$0.5 \mathrm{Ni}-1 \mathrm{Pt} / \mathrm{C}$ & 379 & 9.2 \\
$1 \mathrm{Ni}-1 \mathrm{Pt} / \mathrm{C}$ & 373 & 9.4 \\
$2 \mathrm{Ni}-1 \mathrm{Pt} / \mathrm{C}$ & 366 & 9.5 \\
\hline
\end{tabular}

convert to naphthalene, which is favorable for dehydrogenation selectivity.

The Pt diffraction peaks are clearly seen in Fig. 1, indicating that the Pt species were in a good crystaline form and well dispersed on the support surface. The impregnation sequence has a slight impact on the particle dispersion of the bimetallic catalysts. The Pt diffraction peaks of the $1 \mathrm{Ni}-1 \mathrm{Pt} / \mathrm{C}$ catalyst are slightly broader than those of the other two catalysts, especially at $2 \theta=40^{\circ}$. With increases in the $\mathrm{Ni} / \mathrm{Pt}$ ratio, the Pt diffraction peaks decrease in size, while the $\mathrm{Ni}$ diffraction peaks can be seen to become sharper (Fig. 1(b)). The metal particle size of the supported metal catalyst is correlated with the width of the corresponding diffraction peak. The Pt particle size decreases as the diffraction peak broadens. This implies that the addition of Ni promotes dispersion of Pt. However, too high Ni loading leads to aggregation of $\mathrm{Ni}$ particles.

Figure 2 shows the $\mathrm{NH}_{3}$-TPD profiles of Pt and Pt-Ni catalysts. Both spectra exhibit a single characteristic peak. Normally, the area of a specific peak corresponds to the amount of $\mathrm{NH}_{3}$ desorbed from the sample, and it can be taken as a standard to

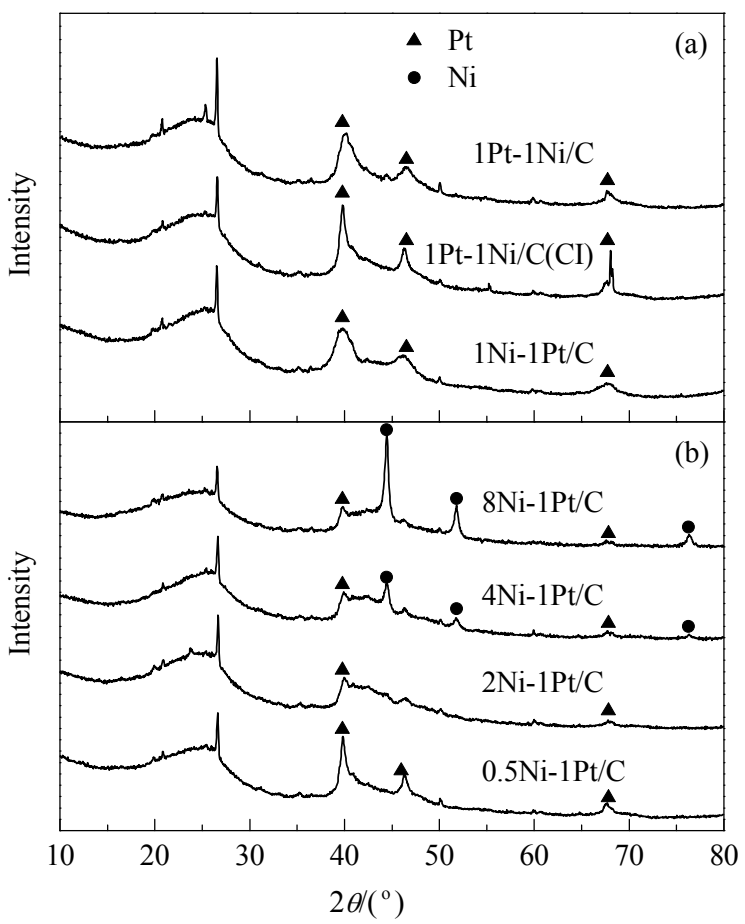

Fig. 1. XRD patterns of carbon supported Pt-Ni bimetallic catalysts prepared by various impregnation sequences (a) and various $\mathrm{Pt} / \mathrm{Ni}$ molar ratios (b).

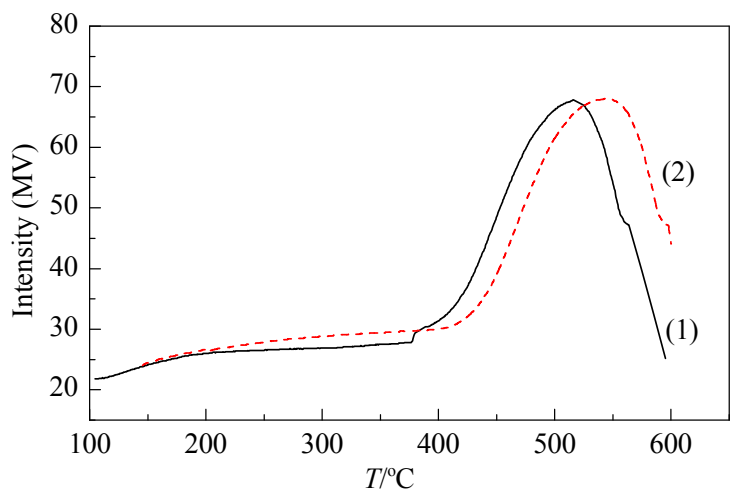

Fig. 2. $\mathrm{NH}_{3}-\mathrm{TPD}$ profiles of $\mathrm{Pt} / \mathrm{C}(1)$ and $1 \mathrm{Ni}-1 \mathrm{Pt} / \mathrm{C}$ (2) catalysts.

quantify the acidity of the sample. Comparing the Pt/C catalyst with the $1 \mathrm{Ni}-1 \mathrm{Pt} / \mathrm{C}$ catalyst, the amounts of desorbed $\mathrm{NH}_{3}$ are similar. However, the peak position of the $1 \mathrm{Ni}-1 \mathrm{Pt} / \mathrm{C}$ catalyst shifts to higher temperatures than that of the Pt/C catalyst. This implies an increase in the strength of acid sites, which is suggested to be associated with the interaction of $\mathrm{Ni}$ and $\mathrm{Pt}$. The $1 \mathrm{Ni}-1 \mathrm{Pt} / \mathrm{C}$ catalyst shows better dehydrogenation activity, indicating that the slight increase of the number of acid centers has a positive effect on the catalytic dehydrogenation activity.

Figure 3 is the product distribution of decalin dehydrogenation over the $\mathrm{Pt} / \mathrm{C}$ catalyst at different temperatures when the decalin feedstock was $1 \mathrm{~mL}$. At this point the catalyst surface was at an overheated liquid film state, having a higher temperature and larger contact area. The results show that the yield for naphthalene keeps increasing from 230 to $290{ }^{\circ} \mathrm{C}$, while the amount of the intermediate product tetralin remains at nearly the same level over this range. This indicates that high temperatures favor the further dehydrogenation of tetralin.

Figure 4 shows the dehydrogenation behavior of decalin over Pt-based catalysts at $290{ }^{\circ} \mathrm{C}$ in a batch reactor. The dehydrogenation of decalin over the $1 \mathrm{wt} \% \mathrm{Ni} / \mathrm{C}$ catalyst was also examined, and the catalytic activity for this sample was nearly zero. The naphthalene yields over $\mathrm{Pt}-\mathrm{Ni} / \mathrm{C}$ bimetallic catalysts were much higher than that obtained over Ni/C or Pt/C monometallic catalysts. On the other hand, both catalytic activity and naphthalene yield over the Pt-Ni catalysts were influenced

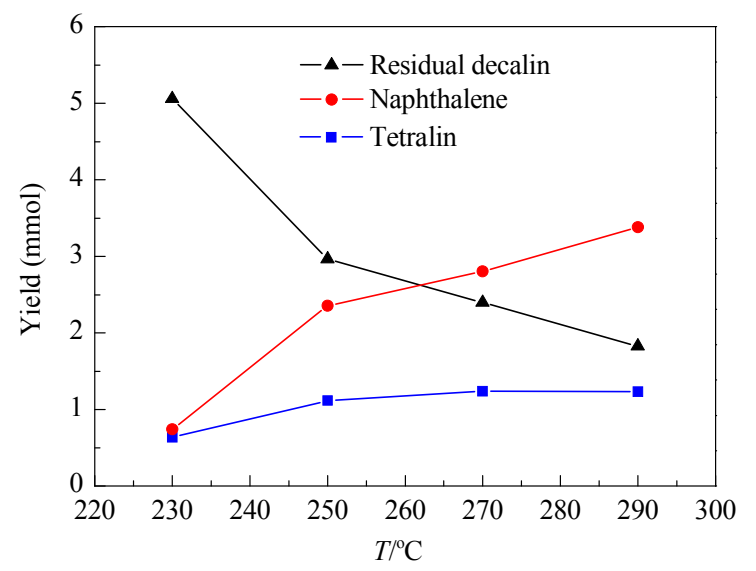

Fig. 3. Effect of temperature on decalin dehydrogenation over the Pt/C catalyst. 


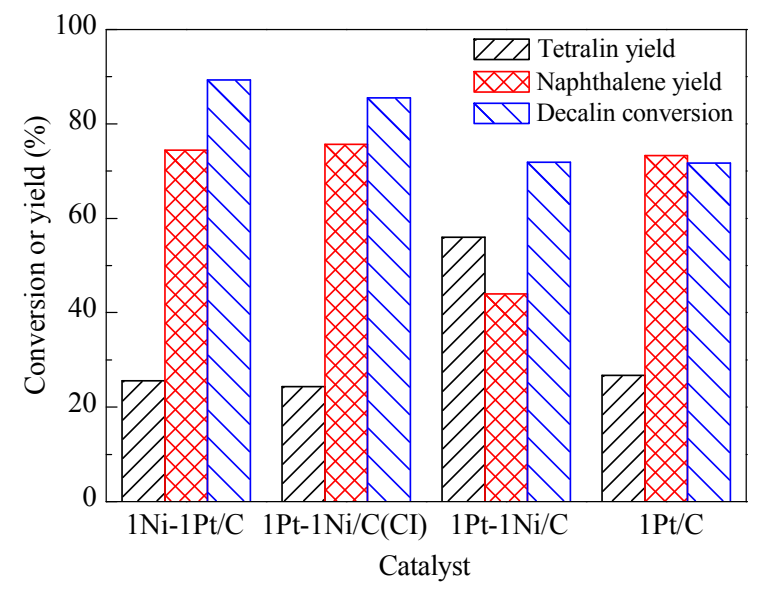

Fig. 4. Decalin dehydrogenation over different Pt-based catalysts in a batch reactor. Reaction conditions: $290{ }^{\circ} \mathrm{C}$, decalin $1 \mathrm{~mL}$, catalyst $0.3 \mathrm{~g}$, $0.5 \mathrm{~h}$.

by the impregnation sequence; they followed the order of $1 \mathrm{Ni}-1 \mathrm{Pt} / \mathrm{C}>1 \mathrm{Pt}-1 \mathrm{Ni} / \mathrm{C}(\mathrm{CI})>1 \mathrm{Pt}-1 \mathrm{Ni} / \mathrm{C}$. The $1 \mathrm{Ni}-1 \mathrm{Pt} / \mathrm{C}$ catalyst, which has Ni residing on top of the Pt substrate, has the best catalytic activity, which is consistent with the DFT results (discussed below). It is most likely that Pt deposited first would remain outside the support and further prevent subsequently deposited Ni from entering the inter cavities of the support, facilitating the formation of the Pt-Ni bond [30,33].

The dehydrogenation activities of decalin over bimetallic catalysts with different $\mathrm{Pt} / \mathrm{Ni}$ molar ratios were discussed in light of Fig. 5. The yield for naphthalene first increased and then decreased with the addition of $\mathrm{Ni}$, while the byproduct tetralin remained nearly unchanged after the $\mathrm{Pt} / \mathrm{Ni}$ ratio exceeded 0.5 . The $1 \mathrm{Ni}-1 \mathrm{Pt} / \mathrm{C}$ catalyst exhibited the best activity and naphthalene yield; its enhanced catalytic activity likely benefits from the formation of the Pt-Ni bimetallic bonds. However, excessive Ni atoms may block the Pt active sites and lead to a decline of the catalytic activity.

In previous work, the hydrogenation activity of Pt-Ni bimetallic catalysts has been correlated to weaker HBEs on bimetallic surfaces $[28,30]$. Herein, DFT calculations were performed to explore whether such correlation can be extended to dehy-

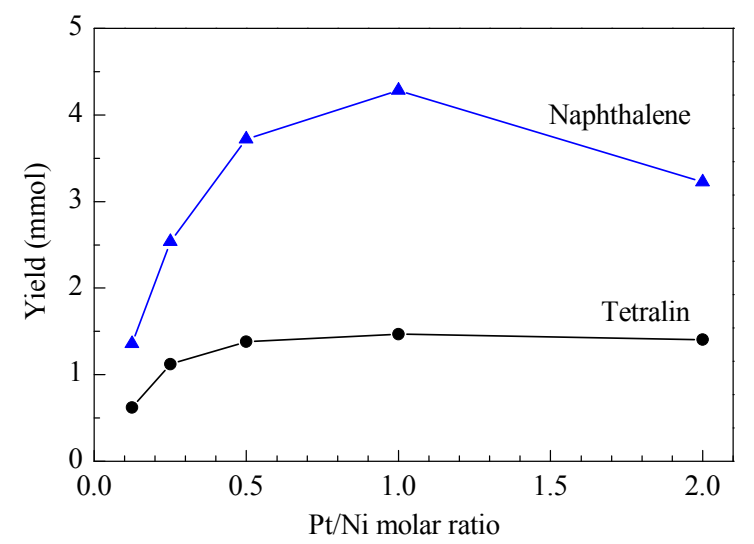

Fig. 5. Effect of the $\mathrm{Pt} / \mathrm{Ni}$ ratio on product yield of decalin dehydrogenation over Ni-Pt/C catalysts. Reaction conditions: $290^{\circ} \mathrm{C}$, decalin 1 $\mathrm{mL}$, catalyst $0.3 \mathrm{~g}$, Pt first impregnated, $0.5 \mathrm{~h}$.
Table 2

Hydrogen binding energies (HBE) on $\mathrm{Pt}(111), \mathrm{Ni}(111)$, and Ni/Pt(111) surface as predicted by DFT.

\begin{tabular}{lc}
\hline Surface & HBE $(\mathrm{kJ} / \mathrm{mol})$ \\
\hline Pt(111) & -267.3 \\
Ni-Pt-Pt(111) & -285.6 \\
Pt-Ni-Pt(111) & -238.3 \\
\hline
\end{tabular}

drogenation. Table 2 shows the DFT results of HBE on the closed-packed Pt(111) surface, the Ni-Pt-Pt(111) surface with a monolayer of Ni residing on top of Pt(111), and the subsurface Pt-Ni-Pt(111) configuration with one monolayer of Ni between the first and second layers of Pt. The DFT calculations were performed using the Vienna ab-initio simulations package (VASP) with spin polarization. The Generalized Gradient Approximation with Perdew Burke Ernzerhof (GGA-PBE) exchange-correlation functional was used. A $3 \times 3$ slab with four metal layers was used to model the adsorption of atomic hydrogen (one adsorbate per unit cell). The top two layers were allowed to relax to the lowest energy configuration while the bottom two layers were fixed at a bulk Pt-Pt bond length as previously described in detail [28,29]. A $3 \times 3 \times 1$ Monkhorst-Pack K-point grid mesh was used to determine the electronic energies.

That the HBE is higher on the Ni-Pt-Pt(111) surface than on either the Pt(111) or Pt-Ni-Pt(111) surfaces suggests that the Ni-Pt-Pt surface structure should be more thermodynamically favored than the other two surfaces for the dehydrogenation reaction. Although more detailed experimental studies are needed in regards to controllable syntheses of bimetallic catalysts, it is clear that the presence of the Ni-Pt-Pt structure is responsible for the higher dehydrogenation activity on the $1 \mathrm{Ni}-1 \mathrm{Pt} / \mathrm{C}$ bimetallic catalyst when compared with the monometallic catalysts and the other two bimetallic catalysts.

\section{Conclusions}

The catalytic dehydrogenation of decalin was investigated using a combination of experimental methods and DFT calculations. Supported Pt-Ni bimetallic and Ni and Pt monometallic catalysts on active carbon were prepared by incipient wetness impregnation and evaluated using a batch reactor for decalin dehydrogenation. The results showed that Pt-Ni bimetallic catalysts had higher dehydrogenation activities than the corresponding monometallic catalysts. The $1 \mathrm{Ni}-1 \mathrm{Pt} / \mathrm{C}$ bimetallic catalyst exhibited the highest activity among all the prepared catalysts toward decalin hydrogenation, which was mostly attributed to the Pt-Ni bimetallic formation. The observed highest activity over $1 \mathrm{Ni}-1 \mathrm{Pt} / \mathrm{C}$ agrees well with DFT results, which predict that the Ni-Pt-Pt(111) surface structures bind hydrogen more strongly than Pt(111) and Pt-Ni-Pt(111).

\section{Acknowledgments}

We would like to acknowledge the technical assistance on computing platform from Professor Xiangdong Ding's Group at Xi'an Jiaotong University. 


\title{
Graphical Abstract
}

Chin. J. Catal., 2014, 35: 1833-1839 doi: 10.1016/S1872-2067(14)60178-9

\section{Hydrogen production from decalin dehydrogenation over $\mathrm{Pt}-\mathrm{Ni} / \mathrm{C}$ bimetallic catalysts}

Suitao Qi*, Yingying Li, Jiaqi Yue, Hao Chen, Chunhai Yi, Bolun Yang Xi'an Jiaotong University

The correlation of experimental results with density functional theory calculations confirmed that bimetallic surfaces with stronger hydrogen binding energies exhibited higher dehydrogenation activity for decalin.

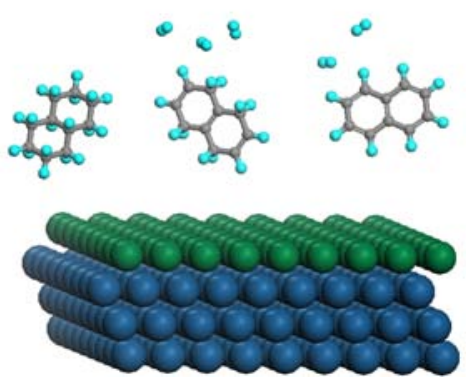

\section{References}

[1] Eberle U, Felderhoff M, Schüth F. Angew Chem Int Ed, 2009, 48: 6608

[2] David E. J Mater Process Technol, 2005, 162-163: 169

[3] Biniwale R B, Rayalu S, Devott S, Ichikawa M. Int J Hydrogen Energy, 2008, 33: 360

[4] Zhu G L, Yang B L. Progr Chem (朱刚利, 杨伯伦. 化学进展), 2009, 21: 2760

[5] Ninomiya W, Tanabe Y, Sotowa K I, Yasukawa T, Sugiyama S. Res Chem Intermed, 2008, 34: 663

[6] Pande J V, Shukla A, Biniwale R B. Int J Hydrogen Energy, 2012, 37: 6756

[7] Kariya N, Fukuoka A, Ichikawa M. Appl Catal A, 2002, 233: 91

[8] Saito Y, Aramaki K, Hodoshima S, Saito M, Shono A, Kuwano J, Otake K. Chem Eng Sci, 2008, 63: 4935

[9] Wang Y G, Shah N, Huffman G P. Energy Fuels, 2004, 18: 1429

[10] Tien P D, Satoh T, Miura M, Nomura M. Fuel Process Technol, 2008, 89: 415

[11] Du J P, Zhao R H, Jiao G R. Int J Hydrogen Energy, 2013, 38: 5789

[12] Chen A B, Zhang W P, Li X Y, Tan D L, Han X W, Bao X H. Catal Lett, 2007, 119: 159

[13] Shukla A A, Gosavi P V, Pande J V, Kumar V P, Chary K V R, Biniwale R B. Int J Hydrogen Energy, 2010, 35: 4020

[14] Shinohara C, Kawakami S, Moriga T, Hayashi H, Hodoshima S, Saito Y, Sugiyama S. Appl Catal A, 2004, 266: 251

[15] Tien P D, Satoh T, Miura M, Nomura M. Energy Fuels, 2005, 19: 731

[16] Tien P D, Satoh T, Miura M, Nomura M. Energy Fuels, 2005, 19: 2110

[17] Wang Y G, Shah N, Huggins F E, Huffman G P. Energy Fuels, 2006, 20: 2612
[18] Jiang N Z, Rao K S R, Jin M J, Park S E. Appl Catal A, 2012, 425-426: 62

[19] Suttisawat Y, Horikoshi S, Sakai H, Abe M. Int J Hydrogen Energy, 2010, 35: 6179

[20] Yolcular S, Olgun Ö. Catal Today, 2008, 138: 198

[21] Nagaraja B M, Shin C H, Jung K D. Appl Catal A, 2013, 467: 211

[22] Patil S P, Pande J V, Biniwale R B. Int J Hydrogen Energy, 2013, 38: 15233

[23] Alhumaidan F, Tsakiris D, Cresswell D, Garforth A. Int J Hydrogen Energy, 2013, 38: 14010

[24] Aboul-Fotouh S M K, Aboul-Gheit N A K. Chin J Catal (催化学报), 2012, 33: 697

[25] Gao X F, Chen C L, Ren S Y, Zhang J, Su D S. Chin J Catal (高旭锋, 谌 春林, 任士远, 张建, 苏党生. 催化学报), 2012, 33: 1069

[26] Biniwale R B, Kariya N, Ichikawa M. Catal Lett, 2005, 105: 83

[27] Qi S T, Yu W T, Lonergan W W, Yang B L, Chen J G. Chin J Catal (齐 随涛, 俞伟婷, Lonergan W W, 杨伯伦, 陈经广. 催化学报), 2010, 31: 955

[28] Qi S T, Yu W T, Lonergan W W, Yang B L, Chen J G. ChemCatChem, 2010, 2: 625

[29] Chen J G, Qi S T, Humbert M P, Menning C A, Zhu Y X. Acta Phys-Chim Sin (陈经广, 齐随涛, Humbert M P, Menning C A, 朱月 香. 物理化学学报), 2010, 26: 869

[30] Chen J G, Menning C A, Zellner M B. Surf Sci Rep, 2008, 63: 201

[31] Skoplyak O, Barteau M A, Chen J G. ChemSusChem, 2008, 1: 524

[32] Hansgen D A, Vlachos D G, Chen J G. Nat Chem, 2010, 2: 484

[33] Shu Y Y, Murillo L E, Bosco J P, Huang W, Frenkel A I, Chen J G. Appl Catal A, 2008, 339: 169

[34] Lima F H B, Zhang J, Shao M H, Sasaki K, Vukmirovic M B, Ticianelli E A, Adzic R R. J Phys Chem C, 2007, 111: 404

\section{活性炭负载Pt-Ni双金属催化剂上十氢化蒜脱氢}

\author{
齐随涛 ${ }^{*}$ ，李迎迎，岳佳琪，陈昊，伊春海，杨伯伦 \\ 西安交通大学化学工程与技术学院化工系, 陕西西安710049
}

摘要: 采用等体积浸渍法制备了活性炭负载的具有脱氢活性的Pt-Ni双金属催化剂及相应的Pt单金属催化剂, 并用X射线衍射、 $\mathrm{N}_{2}$ 吸附-脱附和 $\mathrm{NH}_{3}$-程序升温脱附对其进行了表征. 在 $290{ }^{\circ} \mathrm{C}$ 下, 研究了间歇反应条件下催化剂以过热液膜状态催化十氢化䒺脱氢 活性, 考察了温度、浸渍顺序和 $\mathrm{Pt} / \mathrm{Ni}$ 摩尔比对十氢化芸脱氢活性和菜产率的影响. 结果表明, 与单金属催化剂相比, Pt-Ni双金属催 化剂上产氢效率显著提高. 当 $\mathrm{Pt} / \mathrm{Ni}$ 摩尔比为 $1: 1, \mathrm{Pt}$ 首先浸渍时, 得到的催化剂上脱氢转化率和萘产率最高. 将实验结果与密度泛 函理论计算的氢原子在不同催化表面的结合能关联证实, 具有更强原子氢结合能的双金属表面具有更高的脱氢活性. 
关键词: 铂; 镍; 双金属; 十氢化萎; 脱氢; 密度泛函理论

收稿日期: 2014-04-06. 接受日期: 2014-05-23. 出版日期: 2014-11-20.

*通讯联系人. 电话: (029)82663189; 电子信箱: suitaoqi@mail.xjtu.edu.cn

基金来源：国家自然科学基金(21006076); 高等学校博士学科点专项科研基金(20110201130002); 中央高校基本科研业务费专项 基金(xjj2011062).

本文的英文电子版由Elsevier出版社在ScienceDirect上出版(http://www.sciencedirect.com/science/journal/18722067).

\section{1. 前言}

氢气是一种清洁能源, 在氢燃料电池和替代能源上 有着广阔的应用前景. 但是氢气的储存、运输和配送是 其大规模使用的关键 ${ }^{[1,2]}$. 环烷烃(如十氢化萗、四氢化 荎和环己烷等)可逆加氢脱氢反应的特点使其成为可能 的有机储氢材料 ${ }^{[3-13]}$, 且其储氢密度高, 便于运输, 因此 越来越受关注.

在液态有机氢化物中, 十氢化荎具有较高的质量储 氢密度 $(7.2 \mathrm{wt} \%)$, 因而是最好的储氢材料之一, 且脱氢 反应中无 $\mathrm{CO}_{2}$ 排放, 是一种环境友好型储氢材料 ${ }^{[14-21]}$. 由于十氢化荎脱氢是吸热反应, 高温有利于脱氢的进行, 但高温下也易发生氢解或结焦等副反应, 从而使萗的选 择性下降, 进而阻碍储氢和放氢可逆循环.

双金属催化剂 ${ }^{[22-24]}$ 因其具有与相应单金属不同的 独特的电子和化学特性, 在催化剂设计中会表现出更好

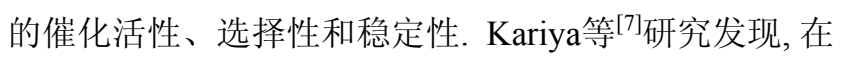
环己烷脱氢反应中, Pt-Re, Pt-Pd和Pt-Rh双金属催化剂 比Pt单金属催化剂更好. 然而, 昂贵的催化剂成本妨碍 了贵金属催化剂的广泛应用, 因此也有研究将金属氧化 物用于催化脱氢反应 ${ }^{[25]}$.

我们前期工作发现铂-镍双金属催化剂是环烯烃(包 括环已烯、1,3-环已二烯和1,4-环已二烯)低温加氢和脱 氢反应的有效催化剂 ${ }^{[26-28]}$. 研究表明, 与相应的单金属 表面相比, 具有Pt-Ni-Pt次表面结构的铂-镍双金属催化 剂, 即 $\mathrm{Ni}$ 原子层位于表层Pt原子下的结构, 具有更高的 加氢活性. 而Ni-Pt-Pt结构的铂-镍双金属催化剂, 即 Ni 原子层位于Pt基体最上方, 表面与吸附质的结合比Pt或 $\mathrm{Ni}$ 单金属表面更强 ${ }^{[29,30]}$, 因此Ni-Pt-Pt表面上强的结合力 有利于环烯烃、含氧化合物 ${ }^{[31]}$ 和氨 ${ }^{[32]}$ 的脱氢.

本文以十氢化菱脱氢作为探针反应来说明双金属 催化剂更好的脱氢活性. 与单金属Pt和 $\mathrm{Ni}$ 催化剂相比, 负载型Pt-Ni双金属催化剂的催化性能更优. 同时, 进一 步讨论了浸渍顺序对Pt-Ni双金属催化剂催化性能的影 响, 并将催化活性与密度泛函理论计算结果进行了关 联 ${ }^{[33,34]}$.

\section{2. 实验部分}

\section{1. 催化剂制备}

采用等体积浸渍法, 将 $\mathrm{Ni}\left(\mathrm{NO}_{3}\right)_{2} \cdot 6 \mathrm{H}_{2} \mathrm{O}(\mathrm{AR}$, 天津化 学试剂研究所)或氯铂酸( $\mathrm{AR}$, 天津化学试剂研究所)浸 渍到活性炭上, 然后在 $110{ }^{\circ} \mathrm{C}$ 下干燥 $2 \mathrm{~h}, 400{ }^{\circ} \mathrm{C} \mathrm{N}$ 下焙 烧 $1 \mathrm{~h}$, 制得Pt或Ni单金属催化剂. 分别采用连续浸渍和 共浸渍法制备Pt-Ni双金属催化剂. 将所制备的不同双 金属催化剂分别记为 $1 \mathrm{Pt}-1 \mathrm{Ni} / \mathrm{C}(\mathrm{CI}), 1 \mathrm{Pt}-1 \mathrm{Ni} / \mathrm{C}$ 和 $1 \mathrm{Ni}-1 \mathrm{Pt} / \mathrm{C}$. 其中, Pt-Ni/C(CI)表示该催化剂用共浸渍法 制备; Pt-Ni/C表示先浸渍Ni金属; $\mathrm{Ni}-\mathrm{Pt} / \mathrm{C}$ 表示先浸渍Pt 金属； $1 \mathrm{Ni}-1 \mathrm{Pt}$ 表示该催化剂中 Ni和Pt原子摩尔比为 $1: 1$. 此外, 还制备出一系列不同 $\mathrm{Pt} / \mathrm{Ni}$ 原子比的Pt-Ni双金属催 化剂以与 $1 \mathrm{Pt}-1 \mathrm{Ni}$ 催化剂进行比较, 分别表示为 $0.5 \mathrm{Ni}-1 \mathrm{Pt} / \mathrm{C}, 2 \mathrm{Ni}-1 \mathrm{Pt} / \mathrm{C}, 4 \mathrm{Ni}-1 \mathrm{Pt} / \mathrm{C}$ 和 $8 \mathrm{Ni}-1 \mathrm{Pt} / \mathrm{C}$. 所有催 化剂中 Pt含量均为 $3 \mathrm{wt} \%$.

\section{2. 催化剂表征}

使用美国Beckman Coulter公司的 3100 Plus型吸附 分析仪测量催化剂在液氮温度下的 $\mathrm{N}_{2}$ 吸附-脱附曲线, 得到催化剂的比表面积和孔径. 催化剂的X射线粉末衍 射(XRD) 谱用Rigaku D/Max-2400型XRD仪测得, $\mathrm{Cu} K_{\alpha}$ 射线, 扫描范围 $5^{\circ}-80^{\circ}(2 \theta)$, 工作电压 $36 \mathrm{kV}$, 工作电流 80 $\mathrm{mA}$. 通过 $\mathrm{NH}_{3}$-程序升温脱附测定催化剂表面酸度, 将 $0.1 \mathrm{~g}$ 样品加入由电炉加热的U形石英管状反应器, 在 $400{ }^{\circ} \mathrm{C} \mathrm{He}(99.99 \%, 30 \mathrm{~mL} / \mathrm{min})$ 下预处理 $0.5 \mathrm{~h}, 30^{\circ} \mathrm{C}$ 下 进行 $\mathrm{NH}_{3}$ 饱和吸附, 通 $\mathrm{He}$ 吹扫 $1 \mathrm{~h}$; 再以 $10^{\circ} \mathrm{C} / \mathrm{min}$ 从 $30^{\circ} \mathrm{C}$ 升至 $600{ }^{\circ} \mathrm{C}$, 热导检测器(TCD)测试脱附信号.

\section{3. 催化剂评价}

不同催化剂上十氢化荎脱氢反应活性采用 $100 \mathrm{~mL}$ 三口平底烧瓶间歇反应装置进行评价. 烧瓶中瓶口装配 冷凝器, 另外两个瓶口分别装取样器和热电偶. 通过连 接有温控仪的电炉来控制反应过程中的温度.

在烧瓶中加入 $0.3 \mathrm{~g}$ 催化剂, 通入 $\mathrm{H}_{2}$ 并加热至反应温 度来还原催化剂 $1 \mathrm{~h}$. 还原结束后, 通入 $\mathrm{N}_{2}$ 吹扫 $30 \mathrm{~min}$ 以 排除反应装置中的 $\mathrm{H}_{2}$. 随后, 加入 $1 \mathrm{~mL}$ 十氢化萗 $(6.48$ $\mathrm{mmol})$ 反应 $0.5 \mathrm{~h}$. 在反应过程中, 十氢化菜持续的蒸发- 
冷凝回流使催化剂表面形成并覆盖十氢化萗液膜, 因此 催化剂表面温度高于十氢化菜的沸点, 十氢化萗处于过 热状态. 用排水法收集和测量反应生成的 $\mathrm{H}_{2}$. 反应结束 后, 向瓶中加入一定量正己烷来溶解反应产物. 最后, 收 集溶解所得的液相产物, 离心分离后通过接有FID检测 器的Fuli 9790 II 型气相色谱仪对产物进行分析. 菜的产 率通过实际生成量与理论生成量的比值而算得.

\section{3. 结果与讨论}

表1列出了不同催化剂的比表面积和孔径. 可见, 负 载金属组分后催化剂的比表面积减小, 表明焙烧后金属 组分进入载体内部孔道而导致催化剂比表面积下降. Pt-Ni双金属催化剂的比表面积按以下顺序递减: $1 \mathrm{Ni}-1 \mathrm{Pt} / \mathrm{C}>1 \mathrm{Pt}-1 \mathrm{Ni} / \mathrm{C}(\mathrm{CI})>1 \mathrm{Pt}-1 \mathrm{Ni} / \mathrm{C}$. 并且随着 $\mathrm{Ni}$ 含 量的增加, Pt-Ni双金属催化剂的比表面积依次下降. 同 时, 对十氢化荎脱氢反应, 较小的孔径阻碍了中间产物 四氢化荎的扩散, 有助于其进一步转化为萗, 从而提高 了脱氢反应的选择性.

由图1的XRD谱可见, 各样品均出现较强的Pt衍射 特征峰, 表明 $\mathrm{Pt}$ 具有良好的晶型且较好地分散于载体表 面. $1 \mathrm{Ni}-1 \mathrm{Pt} / \mathrm{C}$ 催化剂在 $2 \theta=40^{\circ}$ 处Pt的衍射特征峰比另 外两种催化剂稍宽, 说明浸渍顺序对双金属催化剂的颗 粒分散有一定影响. 随着 Ni/Pt摩尔比增加, Pt的衍射峰 越来越小, $\mathrm{Ni}$ 的衍射峰开始出现且峰形越来越尖锐(图 1(b)), 表明 Ni的加入有利于Pt的分散, 使得Pt粒径下降, 而 $\mathrm{Ni}$ 含量过高则导致 $\mathrm{Ni}$ 粒子的团聚.

图 2 为 $\mathrm{Pt} / \mathrm{C}$ 和 $\mathrm{Pt}-\mathrm{Ni} / \mathrm{C}$ 催化剂的 $\mathrm{NH}_{3}-\mathrm{TPD}$ 图. 由图可 见, 两种催化剂均只有一个单峰, 且峰面积相当. 通常, 脱附峰的峰面积对应于样品吸附的氨气量. 由此可知两 种催化剂所吸附的 $\mathrm{NH}_{3}$ 量即酸量差别不大, 但 $1 \mathrm{Ni}-1 \mathrm{Pt} / \mathrm{C}$ 催化剂的脱附峰中心温度更高, 表明 $\mathrm{Ni}$ 的加入使催化剂 酸性增强, 可能增强了 $\mathrm{Ni}$ 和Pt间相互作用. $1 \mathrm{Ni}-1 \mathrm{Pt} / \mathrm{C}$ 催 化剂表现出更好的脱氢活性, 表明酸中心的微弱增强对 催化脱氢有利.

图3 是进料量为 $1.0 \mathrm{~mL}$, 不同温度时 $\mathrm{Pt} / \mathrm{C}$ 催化剂上十 氢化䒺脱氢反应的产物分布. 结果表明, 在 $230-290{ }^{\circ} \mathrm{C}$, 荎的产率随温度升高而增大, 而中间产物四氢化荎的量 几乎保持不变, 说明高温有利于四氢化荎脱氢.

图 4 是 $290^{\circ} \mathrm{C}$ 时 Pt 基催化剂上十氢化荎脱氢反应结 果. 由图可见, $\mathrm{Pt}-\mathrm{Ni} / \mathrm{C}$ 双金属催化剂上十氢化萗转化率 高于相应 $1 \mathrm{wt} \% \mathrm{Ni} / \mathrm{C}$ (几乎为零) 和 $\mathrm{Pt} / \mathrm{C}$ 单金属催化剂.
各双金属催化剂性能顺序为 $1 \mathrm{Ni}-1 \mathrm{Pt} / \mathrm{C}>1 \mathrm{Pt}-1 \mathrm{Ni} / \mathrm{C}(\mathrm{CI})>$ $1 \mathrm{Pt}-1 \mathrm{Ni} / \mathrm{C}$, 可见Pt-Ni催化剂活性和荟的产率受浸渍顺序 的影响, 即 $\mathrm{Ni}$ 位于最外面的 $1 \mathrm{Ni}-1 \mathrm{Pt} / \mathrm{C}$ 催化剂具有更好的 催化活性. 这可能是由于先负载的Pt可能处于载体外表 面, 可阻止随后负载的 $\mathrm{Ni}$ i进入载体内腔, 有助于 $\mathrm{Pt}-\mathrm{Ni}$ 键 的形成 ${ }^{[30,33]}$.

图 5 是不同 $\mathrm{Pt} / \mathrm{Ni}$ 摩尔比的 $\mathrm{Pt}-\mathrm{Ni} / \mathrm{C}$ 催化剂上十氢化萗 脱氢反应结果. 可见, 随着 $\mathrm{Ni}$ 含量增加, 菜的产率先提高 后下降, 其中 $1 \mathrm{Ni}-1 \mathrm{Pt} / \mathrm{C}$ 催化剂活性最好, 菜产率最高. 而当 $\mathrm{Pt} / \mathrm{Ni}$ 原子摩尔比超过 0.5 时, 副产物四氢化萗的量 几乎保持不变, 说明 $\mathrm{Ni}$ 的增加有助于 $\mathrm{Pt}-\mathrm{Ni}$ 双金属键的形 成, 提高了催化活性. 但是, 过量的 $\mathrm{Ni}$ 原子也会阻塞 Pt活 性位, 导致催化活性下降.

我们曾将Pt-Ni双金属催化剂的加氢活性与双金属 表面上的氢结合能相关联 ${ }^{20,22]}$. 本文拟进一步确定这种 关联是否可推及脱氢反应. 表 2 列出 $\operatorname{Pt}(111)$, Ni-Pt-Pt(111)表面和Pt-Ni-Pt(111)次表面三种晶面上氢 结合能的DFT结果. DFT的相关计算采用VASP软件, 电 子交换相关部分在广义梯度近似(GGA)下用标准PBE (Perdew-Burke-Ernzerhof)交换关联泛函进行描述. 四层 的 $3 \times 3$ 平板模型来模拟氢原子的吸附 $(1$ 个单元表面吸附 1 个分子), 并考虑了自旋极化. 表面两层进行弛豫来获 得能量最低的结构, 而底部两层固定 ${ }^{[20,21]}$. 计算中采用 $3 \times 3 \times 1$ 的Monkhorst-Pack K点网格来计算电子的能量.

由表2可见, Ni-Pt-Pt(111)表面上氢结合能的绝对值 比Pt(111)和Pt-Ni-Pt(111)都高, 表明Ni-Pt-Pt表面结构比 其他两种表面在热力学上更有利于脱氢进行. 虽然双金 属催化剂的可控合成还需要更深入的实验研究, 但显而 易见的是, 与相应的单金属催化剂和另外两种双金属催 化剂相比, 存在Ni-Pt-Pt结构的 $1 \mathrm{Ni}-1 \mathrm{Pt} / \mathrm{C}$ 双金属催化剂 具有更高的脱氢催化活性.

\section{4. 结论}

采用等体积浸渍法制备了活性炭负载的Pt-Ni双金 属和 Ni, Pt单金属催化剂, 用间歇反应装置评价了它们 催化十氢化萗脱氢反应性能. 结果表明, 与相应的单金 属催化剂相比, Pt-Ni双金属催化剂具有更好的脱氢活 性, 其中 $1 \mathrm{Ni}-1 \mathrm{Pt} / \mathrm{C}$ 双金属催化剂活性最高. 这可能是由 于Pt-Ni双金属键的形成. DFT结果表明, Ni-Pt-Pt(111) 表面结构上氢的结合能比Pt(111)和Pt-Ni-Pt(111)表面更 强, 因而前者具有更好的脱氢活性. 这与实验结果一致. 